\title{
Consensus
}

Volume 32

Issue 1 Cultural Reception of the Gospel

Article 18

5-1-2007

\section{Reformation Christianity}

Oscar Cole-Arnal

Follow this and additional works at: http://scholars.wlu.ca/consensus

\section{Recommended Citation}

Cole-Arnal, Oscar (2007) "Reformation Christianity," Consensus: Vol. 32 : Iss. 1 , Article 18.

Available at: http://scholars.wlu.ca/consensus/vol32/iss1/18

This Book Reviews is brought to you for free and open access by Scholars Commons @ Laurier. It has been accepted for inclusion in Consensus by an authorized editor of Scholars Commons@ Laurier. For more information, please contact scholarscommons@wlu.ca. 


\section{Reformation History: A People's History of Christianity, Vol. 5}

Peter Matheson, ed.

Minneapolis: Fortress Press, 2006

xviii + 306 pages, $\$ 40.75$ Hardcover

When I took Church History in my seminary back in the 1960s we learned about the great thinkers (all men) and delved extensively into their theology. In short, church history was about "talking heads," a disembodied abstracted set of ideas, all measured against the best of the best, Martin Luther. Women did not exist, and if there was any sense of the grass-roots, either they sat in awe converted by the theology of the geniuses we studied or they were a mindless mob ready to take up with the first demagogue who showed up. Think the Peasants' War and Thomas Müntzer for the standard example. Even when I began to teach the subject at Waterloo Lutheran Seminary in 1975 I used that model more than I care to admit. In a seminary of all but two men women continued to remain absent in my courses, although I strove mightily to bring more radical mass movements of reform into the picture.

This brief personal reminiscence serves to underscore how the discipline desperately needed a social, economic, political and grassroots approach to the events which shaped and defined the growth of movements that followed the carpenter of Nazareth. Indeed, over the three decades of my teaching work after work has appeared correcting this horrendous vacuum. We have witnessed an explosion of books on women within the Christian tradition as well as an extensive number of social and economic histories. Now, at the end of my professorial career I and others are the joyful recipient of studies that give us an infinitely satisfying holistic picture of the two thousand year march of Christianity.

Into this context has appeared a monumental project by Fortress Press in Minneapolis, Minnesota, namely the seven-volume $A$ People's History of Christianity, which concentrates its collected studies at the level of where and how the general populace lived its faith. Each volume is edited by a noted scholar in the field and includes chapters on selected themes by other experts from a variety of faith traditions. The editor of Volume 5, Reformation Christianity, is Peter Matheson, the renowned academic of the Reformation's mass media of woodcuts, broadsheets and pamphlets designed for popular 
consumption. Of course, a work of this nature with its numerous authors runs the danger of uneven quality. In this particular volume, I believe that the chapters are not entirely equal in quality, nor, as might be expected, are they of equal interest to this reviewer. Nonetheless, they are all of high standard and worth the read. The second section "From Cradle to Grave" brought forth immediate yawns; must I go through this? What do I care how ordinary folk dealt with birth, with baptism, with death? Upon reading, however, I was caught up short. By the time I got into these chapters I was tasting the stresses and strains of daily life and piety, the pains, the joys, the fears, the day-to-day belief systems and rituals often lost by those in the ivory towers of academia - Luther, Calvin and yours truly included. In these chapters I walked with people through the rich layers of their daily existence.

Part I deals with how piety old and new reached into both urban and rural centres, and throughout all three sections I was struck to my very being and reminded viscerally how women navigated to find place and how they insisted they be heard in a ruthless patriarchal society. Part III, "Finding Their Voices" proved to be my favourite part, precisely because of the general topic of radical social change in the name of the Reformation Gospel. That theme has been near and dear to my heart for almost forty years. Personally, this volume was a real prize because it gave me what I wanted (Part III), it gave me more of what I expected (Part I) and it took me by surprise and led me forward in knowledge and empathy (Part II). If you want to experience history from the ground, buy this book; indeed, buy them all. Yes, I know they are more expensive than the real "grass-roots" can afford, but we all live in some contradiction.

Oscar Cole-Arnal

Waterloo Lutheran Seminary,

Waterloo, Ontario 